\title{
InfoNorth
}

\section{Krüger's Final Camp in Arctic Canada?}

\section{by Randall C. Brooks, John H. England, Arthur S. Dyke and James Savelle}

$\mathrm{O}$ N 3 July 1999, John England, Art Dyke, and undergraduate student Michelle Laurie were surveying raised marine shorelines on Axel Heiberg Island halfway between Cape Southwest and the mouth of Surprise Fiord. During this work, they discovered a site with objects that appeared to be "of considerable antiquity." The site occupies a beach immediately inland of the modern ice foot and would have provided an accessible camp for anyone traveling by sledge. Shallow, snow-filled gullies entrench the beach on either side of the site.

The site is located on the first "relict" beach above the active beach, about $0.5 \mathrm{~m}$ above high tide. It occupies an area about $10 \mathrm{~m}$ on a side and is without vegetation. The region lacks prominent landmarks, and the raised beaches are sandy and subject to wind erosion and sand drift. During the early summer visit, only the knoll, where the camp appears to have been, was exposed. The beach-face ramp and the adjacent gullies were still entirely filled with snow and ice. Some of the tent canvas remnants were embedded in the snow banks. For a search team on the ice passing by the area in late winter, this site and its remnants would not have been visible.

Objects found on the site included a wooden box containing a small transit (with spare parts and tools), an unopened tin of food, an enameled metal cup and plate, a small compass, a heavy canister with cork stopper probably intended to hold fuel or spirits (about two gallons in capacity and galvanized, or at least unrusted), and a small pile of rock samples. Only the compass and the transit were collected for preservation and identification. Protruding through the surface sand was evidence of additional material, including what appeared to be tent canvas, as well as printed material and a shirt (or long underwear) with label of German origin. Most of the artifacts were still on the surface, though some items were partially buried in winddrifted sand. The compass, for example, was about $95 \%$ buried, lying face up in the centre of the site. The transit box, found near the west side of the site, was only slightly settled into the sand. The item of clothing was inconspicuous at first, being largely drifted over. It had wooden buttons, and the label was still attached to the collar. This subsurface material was left undisturbed, to await the proper archaeological survey of this site that the Nunavut government is planning for this summer.

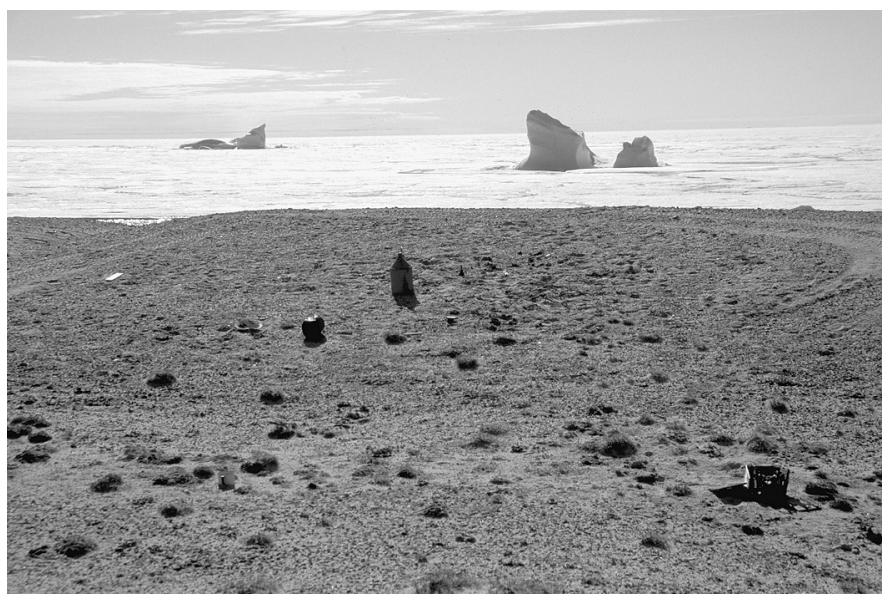

The transit and other artifacts, as found in 1999 on the beach, Axel Heiberg Island, Nunavut. (Photo: J. England.)

No bones were seen at the site, neither human bones nor food refuse. The lack of food refuse would indicate a brief stay, during which the site occupants used only canned food. Also, the occupants do not appear to have abandoned firearms or their sledge at the site, nor did we see anything resembling tent poles or sleeping-bag remnants. This may indicate that they continued on; or, given the surviving tent and clothes, the team may have gone out hunting for food in desperation but never made it back to the camp, being caught by a late winter storm or falling from exhaustion. Thorsteinsson (1961) had suggested that a campsite of Hans Krüger's might be found at or near Hell Gate, but this now seems unlikely, as Hell Gate lies between the southwest extremity of Ellesmere Island and North Kent Island, far to the south of the team's intended path to Bache Post.

As both England and Dyke are well acquainted with the history of Arctic exploration, they began to consider who might have left the instrument, and under what circumstances, given its evident value. Among the rock samples were some fossil specimens, with at least one rather nice mineral specimen (possibly prairie rose, or a gypsum growth). The abandoned samples clearly identified the site as a geological camp. The abandonment of specimens would be consistent with a team in some difficulty. With respect to the transit and compass, subsequent enquiries by England and Dyke, and by Savelle, failed to establish a 
source. In 2003, these individuals contacted the senior author at the Canada Science and Technology Museum (CSTM) in Ottawa. An initial assessment of the photos reinforced the view that the transit and compass (found some $5 \mathrm{~m}$ apart) belonged together, and this was confirmed when the instruments arrived at the CSTM. Although the compass carries no maker's marks, it is designed to fit across the transit's trunnions and has a pin that fits a hole on the transit. The finish and patina on the compass are also the same as on the transit.

The transit is signed "Max Hildebrand früher August Lingke u. Comp. G.m.b.H. Freiberg Sachsen" (Max Hildebrand, formerly August Lingke and Company, Ltd., Freiberg, Saxony). It is also engraved with the Hildebrand trademark and with the letters "H W F." Initial searches for information on the maker, Max Hildebrand, turned up only very basic information and failed to provide an end date for the firm's activities. However, a paper by J.B. te Pas (1998) soon solved that problem, indicating that the longlived firm had roots traceable to 1791 . We now know that the original firm was taken over by August Lingke in 1859 and came into Max Hildebrand's ownership in 1873. The specific name of the firm displayed on the instrument indicates that it postdates 1889 but predates ca.1921, when the Hildebrand firm acquired the assets of the instrument makers Gebr. Wichmann (Wichmann Brothers). The new firm became Hildebrand-Wichmann-Werke, an important detail discussed below.

\section{THE POSSIBILITIES}

The northwestern Arctic Islands were first explored by Otto Sverdrup in 1898-1902. Sverdrup and several members of his crew reached southern Axel Heiberg Island during spring sledging trips to the westernmost islands in 1900 and 1901, traveling from their base on southern

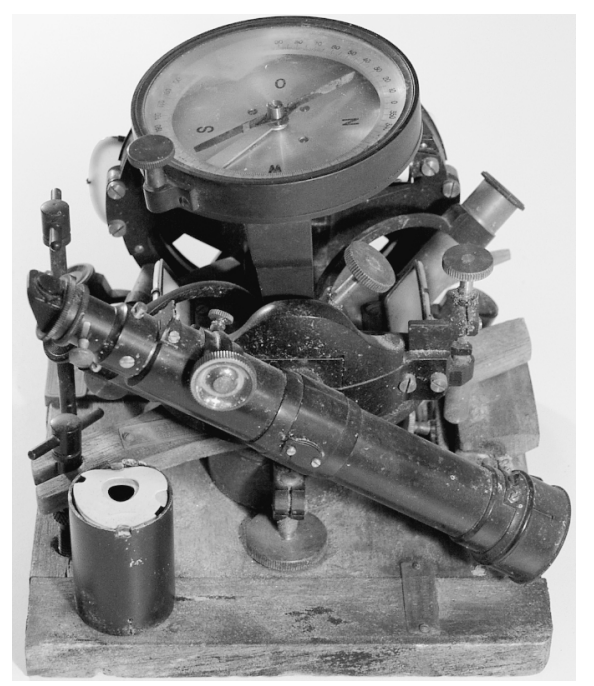

The Max Hildebrand mountain transit, with the compass mounted as normally used.
Ellesmere Island, where Fram was moored. Because Sverdrup's group was in good health, there would have been no apparent reason for them to abandon a valuable scientific instrument and other provisions at this time. During the next decade, other groups explored the Canadian High Arctic, including Peary (1906), Cook (1908), and Stefansson (1916); however, none of these individuals recorded visits close to southern Axel Heiberg Island. Hence, aside from Sverdrup, Hans Krüger (1930) remains the only plausible source for the instrument that we can think of, even though his journey up until his disappearance, as currently known, did not include the site in question (see below). However, the new site is on the general path Krüger had planned to take on his journey back to the RCMP's Bache Peninsula detachment on Ellesmere Island. Operation Franklin, conducted by the Geological Survey of Canada in the 1950s, included southern Axel Heiberg Island, where survey points and fuel caches are still evident. However, no mention was made of the site we are describing. Up to the present day, this coastline has remained one of the least documented areas of the archipelago.

Dr. Hans Kurt Erich Krüger was born in Prussia in 1886. After training as a lawyer, Krüger traveled to South West Africa (now Namibia), where he was involved with mining. After World War I, Krüger returned to Germany, where he audited courses in geology at the Technische Hochschule in Darmstadt and began to plan an Arctic expedition. His plans, outlined in a paper published in Petermanns Mitteilungen (Anonymous, 1924), were influenced by the writings of Vilhjalmur Stefansson (1921), who had ventured across the western Arctic in 1916, living off the land. Krüger corresponded with Stefansson, who warned him of the dangers and problems that he would encounter (Barr, 1993).

By 1925, Krüger was accumulating equipment and, while seeking sponsors, had begun writing Canadian

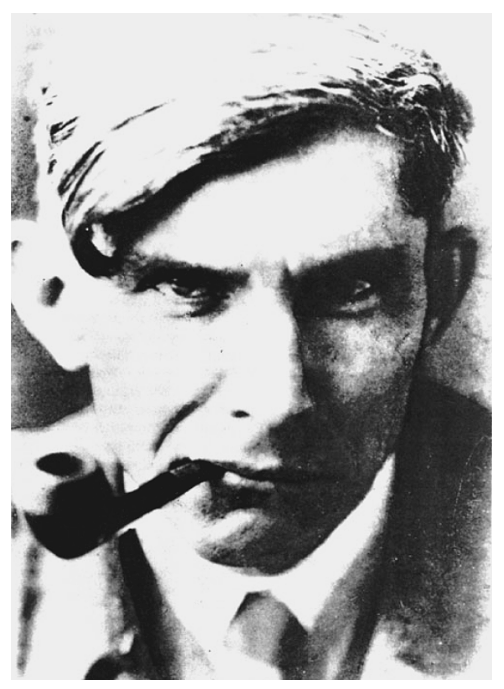

Hans Kurt Erich Krüger, ca. 1925. Courtesy Archiv der Technischen Hochschule, Darmstadt, Germany. 
officials to obtain authorization for the trip. In that same year, he and Prof. F. Klute traveled to Greenland (on the so-called Hessian West Greenland Expedition) to test equipment and carry out geological observations. While awaiting permission to enter Canadian territory (delayed until late 1929), Krüger made a second trip to Greenland, having hired a Danish assistant, Åge Rose Bjare, to act as guide and interpreter. In Greenland, they conducted fieldwork along with other geologists who had come on the same ship. Later that year, Krüger and Bjare travelled north by ship via Ellesmere Island to Northwest Greenland, where they finally received word that their Canadian expedition had been approved.

During the late autumn of 1929 and the following spring, they made a trip into the interior of Northwest Greenland. During this trip, they contracted what is believed to have been trichinosis from the meat they were eating. This illness may have later contributed to some of the two men's problems on the Canadian trip, and hence to their disappearance. For example, we learn from various reports that Krüger was thin and frequently sick even when the party of three (Krüger, Bjare, and Akqioq, an experienced Inughuit guide from Greenland) initially set off from Bache Peninsula on Ellesmere Island. The three explorers were accompanied by their supply team as far as western Ellesmere Island, after which they set off alone around 1 April 1930, heading north through Eureka Sound. Their single sled was so heavily loaded that the $15 \mathrm{dogs}$ could not pull it unaided by the men. The three explorers were never seen again. Several subsequent finds have allowed others to document their path from Ellesmere to northernmost Axel Heiberg Island, from which they progressed to their final known landfall on Meighen Island, the outermost island on the polar continental shelf. Here their trail ends.

\section{ATTEMPTS TO FIND THE EXPEDITION}

During 1931 and 1932, the Royal Canadian Mounted Police (RCMP) made several extended expeditions to try to locate Krüger, but to no avail. The only evidence found was a note, discovered by RCMP Corp. H.W. Stallworthy in 1932, which Krüger had left two years earlier (on 24 April 1930) in a cairn originally built by R.E. Peary in 1906. This cairn is located at Cape Thomas Hubbard, on the northern tip of Axel Heiberg Island. Krüger's note intimated that he was heading for Meighen Island. Not until 1954 was a second note located at Lands Lokk, northwestern Ellesmere Island, in another cairn built by Peary. This note, found by Canadian glaciologist Geoffrey Hattersley-Smith, had been dated by Krüger two days before he reached Cape Thomas Hubbard. A final note, signed by Krüger and dated 5 May 1930, was found by Canadian geologist Ray Thorsteinsson in 1957, at Andersen Point, Meighen Island. In this note (Thorsteinsson, 1961), Krüger reported that he was bound for Cape Sverre, Amund Ringnes Island, about $200 \mathrm{~km}$ to the south. No mention

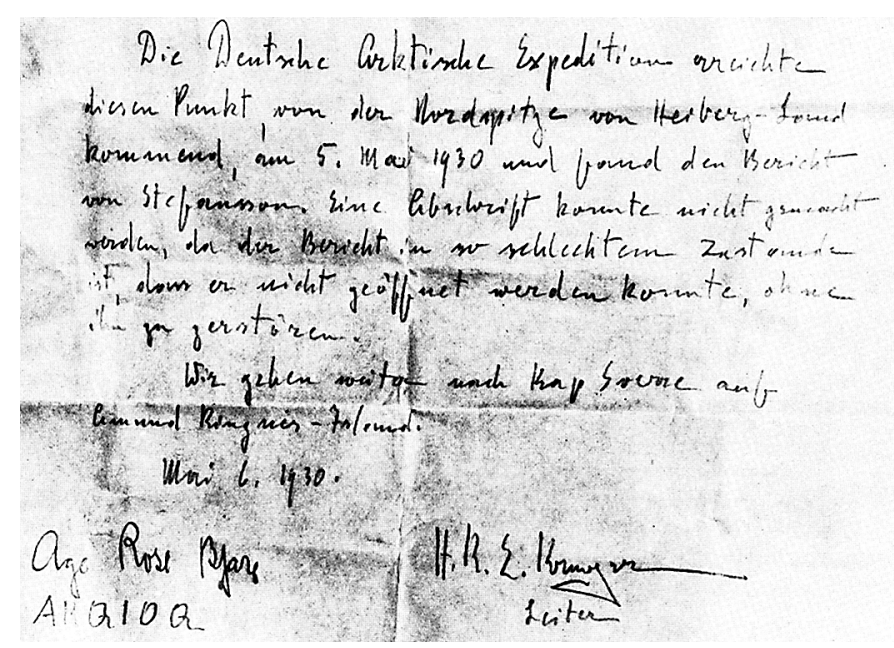

Krüger's final note, dated 5 May 1930, and signed also by Bjare and Akqioq. It was found in 1957 at Anderson Point, Meighen Island, in a cairn that Stefansson had erected in 1916.

was made of possible problems. At this point, the trail went cold for more than 40 years, until the find on Axel Heiberg Island reported here.

\section{ESTABLISHING THE LINK}

Attempts to link the instrument directly to Krüger using archival sources in Europe have proved unfruitful. A list of items carried on the expedition survives: “... pemmican for men and dogs, a quantity of tea, one case of ammunition, two rifles, three cans of coal oil (about 15 gallons), primus lamps, deerskin sleeping bags, clothing, camp equipment, double tent, snowshoes, skis, heavy scientific equipment, a deep sea sounding wire (very heavy), and other miscellaneous equipment..." (Barr, 1993:289). One may only presume that, if the small mountain transit was Krüger's, it was included amongst the "heavy scientific equipment." Attempts to locate a list of the equipment Krüger had acquired through the Technische Hochschule (now the Technische Universität), and through other researchers in Germany familiar with his career, have also been unsuccessful, as were inquiries to Hildebrand's successor firm in Freiberg, FMP Holdings. Unfortunately, the assets of the Hildebrand firm were removed to Russia as war reparations after World War II, and although it is quite possible that the firm's records are preserved in Russian archives, they have not been located.

However, while the transit was being photographed at the Canada Science and Technology Museum, it was noticed that the firm's trademark had been modified after production. If one rotates the instrument $30^{\circ}$, it is clear that the name and trademark on the vertical circle were engraved and filled with gold or lacquer in one operation. However, continuing to rotate the instrument, one sees that three more letters-H W F-have been added subsequently to the trademark. Furthermore, the "finish" of the 


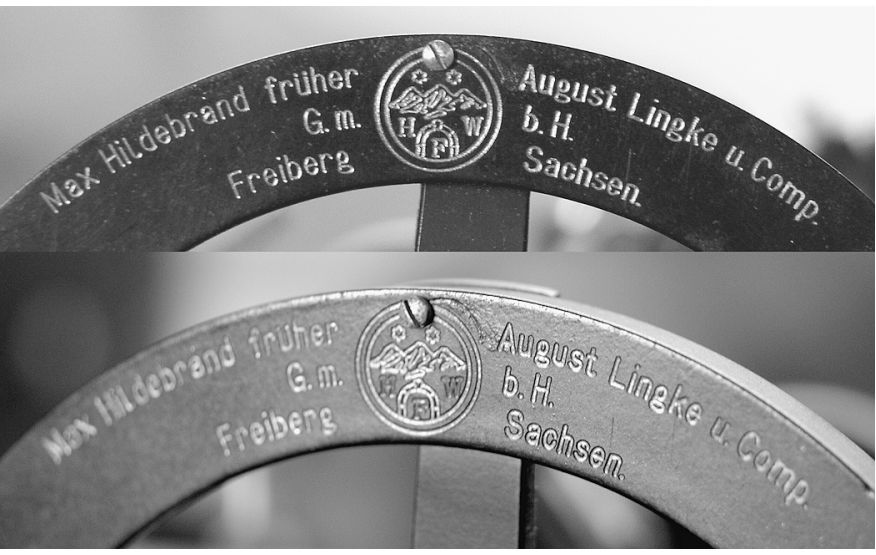

Details of the Hildebrand trademark on the transit seen from straight on (top) and at a $30^{\circ}$ angle. Note the marked difference in appearance of the " $\mathrm{H} W \mathrm{~F}$ " within the circle.

new engraving is slightly different. As it turns out, the letters $\mathrm{H}, \mathrm{W}$ and $\mathrm{F}$ stand for Hildebrand, Wichmann, and Freiberg. Collectively, these initials indicate that, although the instrument itself dates to ca. 1919-1921, the modification of the trademark limits its age to ca. 1921 or shortly thereafter, when the new partnership with Wichmann was established. Furthermore, a 1925 Hildebrand catalogue for "Der Kleine Hildebrand" (the specific model found), shows the trademark further modified so that the letters had become "H R W" (Hildebrand, 1925). This catalogue, now in the possession of Joop te Pas, gives the price for the "Kleine Hildebrand" as 529 Reichmarks. (It should be recalled that Germany had been in a period of hyperinflation following World War I.)

This information clearly establishes that the instrument found on Axel Heiberg was sold by Hildebrand ca. 19211925. Since Hildebrand's small mountain transits are also known to have been used by other Arctic explorers, Krüger may have been influenced in his acquisition of one for his expedition. Therefore, we feel that there is compelling evidence that the transit belonged to Krüger.

\section{CONCLUSION}

From Krüger's three notes, we know that he traveled westward across Ellesmere Island via Sverdrup Pass, then turned northward to circumnavigate Axel Heiberg Island and continued counterclockwise down its west coast. In the process, Krüger's party took a side trip westward to Meighen Island, where his last surviving message (dated 5 May 1930) was found two decades later. In the early searches, and subsequently, it has been assumed that Krüger would have continued southward either to Cape Sverre, Amund Ringnes Island, as his note indicated, or to southern Axel Heiberg Island, which he would have had to round before entering Eureka Sound. From there, he would have continued through Sverdrup Pass, returning to Bache Post (RCMP) before winter set in.
The 1999 find described here now provides the best evidence concerning the probable fate of Hans Krüger and his team. The German label on the partially buried clothing, the fragment that appears to be tent canvas, the oldstyle canister, the small pile of rock samples, and most significantly, the evidence gleaned from the small transit, point to new evidence concerning this 70-year-old Arctic mystery. Why would one abandon such easily transported and important possessions that would constitute the very heart of the scientific expedition? The overriding impression that one is left with at this sparse site is its abandonment under duress. The fact that so few provisions remained, and that the tent itself may have been destroyed, suggests that the camp may have suffered a late spring snowstorm that buried what remained, and the explorers had no time or energy left to excavate it before escaping eastward. Regardless, if the site is Krüger's, then his team made it several hundred kilometres farther back on their return journey than was previously thought.

Sadly, Krüger's fiancé and mother never had conclusive evidence of their loss, and their anguish is revealed in letters sent to Krüger via the RCMP in 1931, now preserved in the Library and Archives Canada. His fiancé never married and tragically committed suicide in 1946. We hope that the planned archeological survey of the subsurface and the snow-filled gullies adjacent to the site will help clarify what we have presented here, further confirming that this is Krüger's final camp. Since scientific surveys, including ours, have been so widely conducted along the coastlines to the east that lead into and through Eureka Sound, it is unlikely that any subsequent camp will be found.

\section{ACKNOWLEDGEMENTS}

J. England and A. Dyke thank the Polar Continental Shelf Project, Natural Resources Canada, for providing logistical support to the geological research survey that inadvertently led to their discovery of this site, and the Natural Sciences and Engineering Research Council of Canada (Discovery Grant A6880 to JHE) that funds that research. Michelle Laurie, then a student at the University of Alberta, we thank for field assistance during the summer of 1999. The authors wish to thank the following for their assistance during the research for this paper: Joop te Pas (the Netherlands), William Barr (Arctic Institute of North America, University of Calgary), Cornelia Luedecke (University of Munich), Marianne Viefhaus (Technische Universität, Darmstadt), and Gundrum Wolfschmidt (Universität Hamburg).

\section{REFERENCES}

ANONYMOUS. 1924. North Pole expedition planned to the north of the Franklin Islands. Petermanns Mitteilungen 70:232.

BARR, W. 1993. The career and disappearance of Hans K.E. Krüger, Arctic geologist, 1886-1930. Polar Record 29(171):277-304. 
HILDEBRAND G.m.b.H. 1925. Der Kleine Hildebrand: Das kleinste Reise-Universal-Instrument. Freiberg, Germany: Hildebrand G.m.b.H.

KRÜGER, H.K.E. 1929. Recent geological research in the Arctic. American Journal of Science, Series 5(17):50-62.

te PAS, J.B. 1998. Max Hildebrand, late August Lingke \& Co. G.m.b.H. Bulletin of the Scientific Instrument Society 58: $19-21$.

STEFANSSON, V. 1921. The friendly Arctic: The story of five years in polar regions. New York: Macmillan.

THORSTEINSSON, R. 1961. The history and geology of Meighen Island, Arctic Archipelago. Geological Survey of Canada, Bulletin 75 .
Randall C. Brooks is the curator of Physical Sciences and Space at the Canada Science and Technology Museum, Ottawa, Ontario K1G 5A3, Canada; rbrooks@technomuses.ca

John $H$. England is a professor in the Department of Earth and Atmospheric Sciences, University of Alberta, Edmonton, Alberta T6G 2E3.

Arthur S. Dyke is a research scientist with the Terrain Sciences Division, Geological Survey of Canada, Ottawa, Ontario K1A OE4, Canada.

James Savelle is a professor in the Department of Anthropology, McGill University, Montreal, Quebec H3A 2T7, Canada. 